\title{
Whiskers in indium tin oxide films obtained by electron beam evaporation
}

\author{
S. I. Castañeda, ${ }^{\text {a) }}$ F. Rueda, ${ }^{\text {b) }}$ R. Díaz, J. M. Ripalda, and I. Monteroc) \\ Laboratorio de Física de Materiales, Departamento de Física Aplicada C XII, \\ Universidad Autónoma de Madrid, 28049 Madrid, Spain
}

(Received 20 January 1997; accepted for publication 3 November 1997)

\begin{abstract}
Indium tin oxide thin films consisting mainly of whiskers have been deposited on glass by electron beam evaporation. Low deposition rates $(35 \AA / \mathrm{min})$ and substrate temperatures in the $120-400{ }^{\circ} \mathrm{C}$ range were used. Morphology by scanning electron microscopy, crystal structure, energy dispersive analysis of x-rays, and x-ray photoelectron spectroscopy compositions, optical and conducting properties of films have been studied as a function of temperature of growth and further annealing in air. Whiskers associate and produce flatter surfaces, the grain size increases from $\approx 390 \AA$ to $\approx 790 \AA$, keeping however its fibrous structure after $400{ }^{\circ} \mathrm{C}-30 \mathrm{~min}$ annealing. In films deposited at temperatures below $200{ }^{\circ} \mathrm{C}$, next to cubic $\operatorname{In}_{2} \mathrm{O}_{3}$, tetragonal $\mathrm{Sn}$ and cubic $\operatorname{In}_{2} \mathrm{Sn}_{2} \mathrm{O}_{(7-x)}$ appear. During growth and after air annealing $\mathrm{Sn}^{4+}$ segregates to the surface, attaining $\mathrm{Sn} / \mathrm{In}$ concentration ratios of 4.6. On air annealing the optical transmittance and electrical resistance increase, in some cases from $2 \%$ to $90 \%$ and by a factor of about 4, respectively. (c) 1998 American Institute of Physics. [S0021-8979(98)01004-4]
\end{abstract}

\section{INTRODUCTION}

Indium tin oxide (ITO) in thin film is used as transparent electrode, due to a high transmittance in the visible spectral range and high electrical conductivity. The high reflectance of ITO in the infrared permits its use as selective window. Other applications include optical information displays and optoelectronic devices, such as solar cells. Besides, ITO has also applications in thermal control and photochronic devices. Its use as an optical memory element by using the bleaching of dark ITO when illuminated with a laser has been suggested. ${ }^{1}$ By electron beam evaporation, Hamberg and coworkers ${ }^{2,3}$ have obtained ITO with low absorption in the visible $(\approx 2 \%)$ high reflectance in the thermal infrared $(90 \%)$, and resistivity of $3 \times 10^{-4} \Omega \mathrm{cm}$. Other conditions were a partial pressure of $\mathrm{O}_{2}$ of $5 \times 10^{-4}$ Torr and substrate temperature $\left(T_{\mathrm{s}}\right)$ in the range of $150-350{ }^{\circ} \mathrm{C}$. The alternative ITO deposition method studied in more detail until now, has been reactive sputtering. The optical and electrical properties of the resulting compact films have been studied. ${ }^{4-6}$ Substrate temperature and oxygen partial pressure during deposition have been reported to affect crystalline phase, grain size, electrical conductivity, and optical transmittance of thin films. The presence of In metal observed in ITO films when deposited by sputtering, without oxygen in the discharge, was reported by Andrade and Moehlecke. ${ }^{1}$ Banerjee et al. ${ }^{4}$ concentrate on the effect of $T_{\mathrm{s}}$, oxygen partial pressure $\left(2-8 \times 10^{-5}\right.$ Torr range), and growth rates $(20-300 \AA / \mathrm{min})$ on transmittance and resistance, having obtained the best transmittance/sheet resistance ratio at $300{ }^{\circ} \mathrm{C}, 8 \times 10^{-5}$ Torr

\footnotetext{
${ }^{a}$ Corresponding author: on Leave from Dept. of Physics, Facultad de Ciencias Físicas, Universidad Nacional Mayor de San Marcos. Ciudad Universidad, Av. Venezuela s/n-Lima 1-Telefax: 51-14-521343, apartado postal 14-0149, Lima-Perú. Electronic-mail: saul.castanneda@uam.es

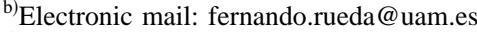

c) At CSIC, Instituto de Ciencia de Materiales de Madrid.
}

$\mathrm{O}_{2}$ partial pressure, and grain sizes of 300 to $400 \AA$. For $T_{\mathrm{s}}>250{ }^{\circ} \mathrm{C}$, the effect of $\mathrm{O}_{2}$ partial pressure is thought to limit the concentration of oxygen vacancies, which affects the electrical and optical properties, without affecting either the crystalline phase (cubic $\operatorname{In}_{2} \mathrm{O}_{3}$ ) or the grain size. However, it is not quite explained why, for increasing $\mathrm{O}_{2}$ partial pressures, there is an increase in carrier concentration (Table II of Ref. 4). The optical band gaps are reported to shift to higher energies, this being related to the carrier concentration through the Burstein-Moss shift. ${ }^{4,7}$ Frank and coworkers in their study of the properties of sintered ITO powders report a Sn solubility limit of $6 \pm 2$ at. $\%$ in $\operatorname{In}_{2} \mathrm{O}_{3}$ and conclude that all $\mathrm{Sn}$ atoms in solution are active donors. ${ }^{8}$ Elfallal et al. ${ }^{9}$ vary the $\mathrm{O}_{2}$ partial pressure and study the effect of postdeposition thermal treatments in air or controlled $\mathrm{N}_{2}-\mathrm{H}_{2}$ atmospheres on the electrical and optical properties. They conclude that, regardless of growth conditions, the postdeposition treatments affect these properties most. ${ }^{5,6} \mathrm{In}$ more recent work, Elfallal et al. present a model to link the electron concentration to the $\mathrm{SnO}_{2}-\mathrm{In}_{2} \mathrm{O}_{3}$ composition, ex-

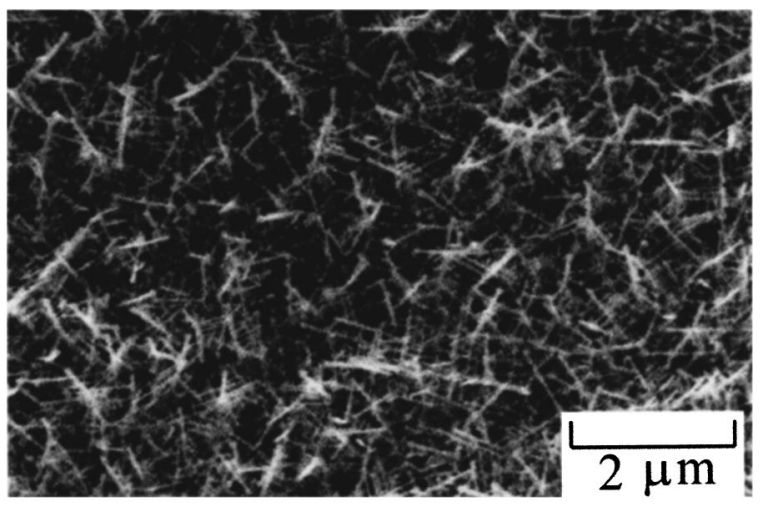

FIG. 1. SEM micrograph of an ITO film (ITO 8) grown at $350{ }^{\circ} \mathrm{C}$. 


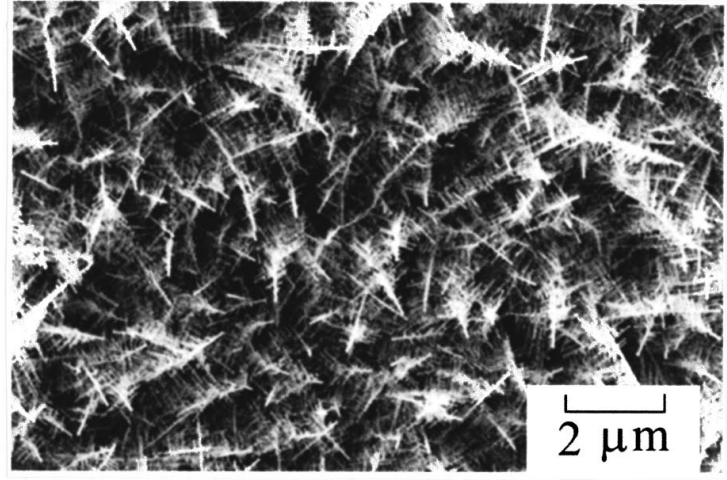

(a)

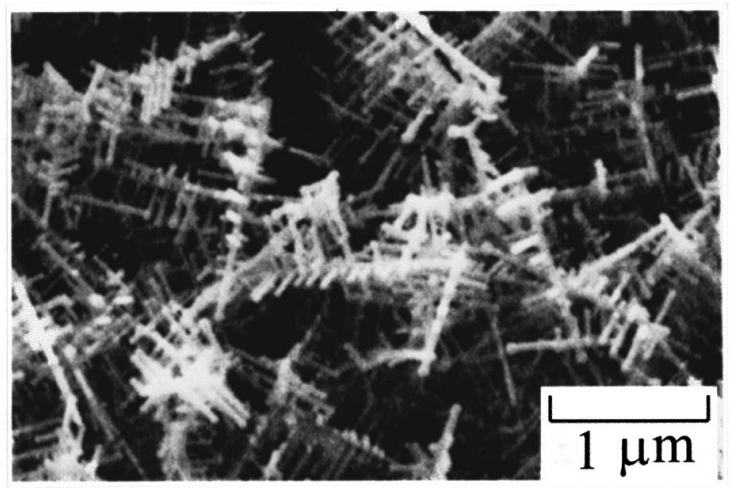

(b)

FIG. 2. SEM micrograph (a) of an ITO film (ITO 10) grown at $400{ }^{\circ} \mathrm{C}-6000 \times$ magnification, (b) same film at $20000 \times$ magnification.

plaining the presence of a broad concentration maximum for $7-15$ at. $\% \mathrm{Sn}$ and $650 \mathrm{~K}<T_{\mathrm{s}}<770 \mathrm{~K}$. On annealing, the "reduction of the number of active Sn lattice sites" is attributed by these authors to the tendency to form Sn clusters.

On substrates with a temperature gradient Rauf has studied by transmission electron microscopy and tunneling scanning microscopy the morphology of ITO films of 5.1 and 6.6 at. \% Sn deposited by electron bombardment. Apart from some degree of preferential orientation no whiskers were observed. ${ }^{10,11}$

The growth of whiskers by electron beam evaporation/ deposition process has been reported in titanium and beryllium by Bunshah and Juntz ${ }^{12}$ at around $840{ }^{\circ} \mathrm{C}$, at high deposition rates $(250000 \AA / \mathrm{min})$.

The presence of whiskers at the surface of ITO films when grown at $T_{\mathrm{s}}=300{ }^{\circ} \mathrm{C}$ under an electron shower irradiating the substrate, has been reported by Yumoto et al. ${ }^{13}$ These authors suggest that the electron shower activates the oxidation of In and Sn, even in oxygen deficient films, producing films with resistivities one order of magnitude smaller than those of films just $e$-beam evaporated $\left(10^{-4}\right.$ and $10^{-3} \Omega \mathrm{cm}$, respectively). As far as we know, no fibrous, crystalline dendritic structure in $e$-beam evaporated ITO for substrate temperatures in the $120-300{ }^{\circ} \mathrm{C}$ range has been reported as yet. In this work, we have obtained mainly fibrous ITO films without recourse to electron shower. Growth conditions, and $T_{\mathrm{s}}$ in particular, have been studied. As $T_{\mathrm{s}}$ may affect the film composition drastically, energy disper-

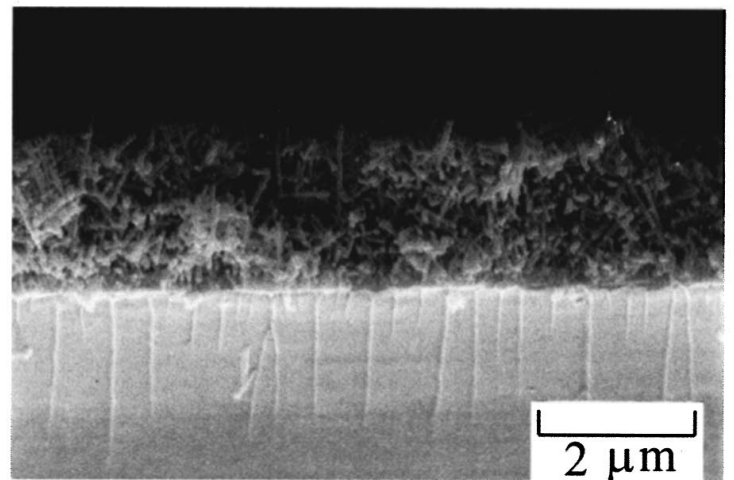

(a)

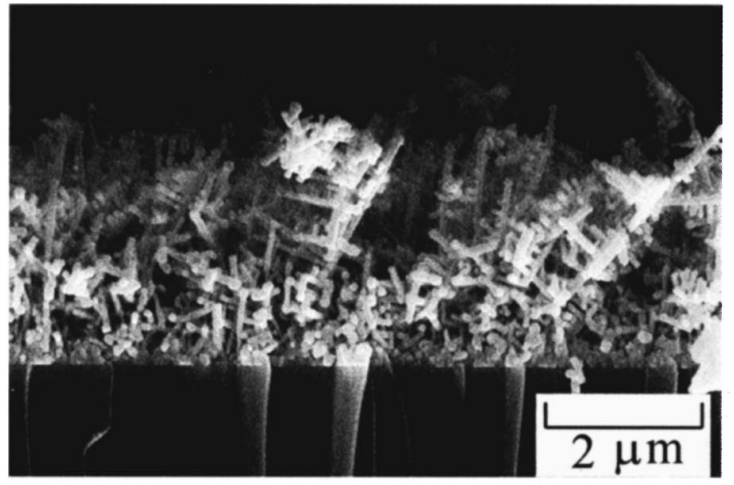

(b)

FIG. 3. SEM micrograph of cross section (a) of an ITO film (ITO 10) grown at $400{ }^{\circ} \mathrm{C}$, (b) other ITO film (ITO 9) grown at $365^{\circ} \mathrm{C}$.

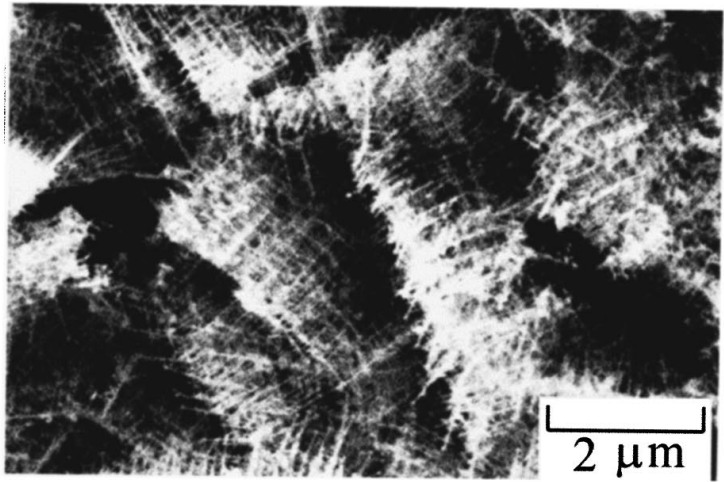

(a)

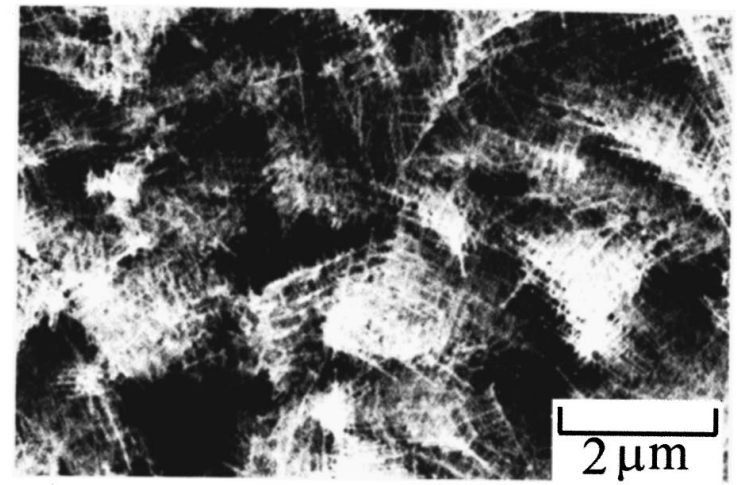

(b)

FIG. 4. SEM micrograph (a) of an ITO film (ITO 8) grown at $350{ }^{\circ} \mathrm{C}$ and air annealed at $350{ }^{\circ} \mathrm{C}$-30 min, (b) same sample further air annealed at $400{ }^{\circ} \mathrm{C}$ $30 \mathrm{~min}$. 


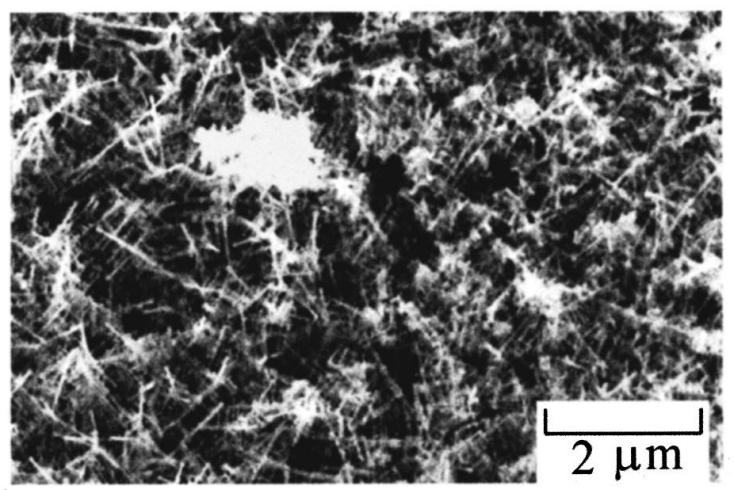

(a)

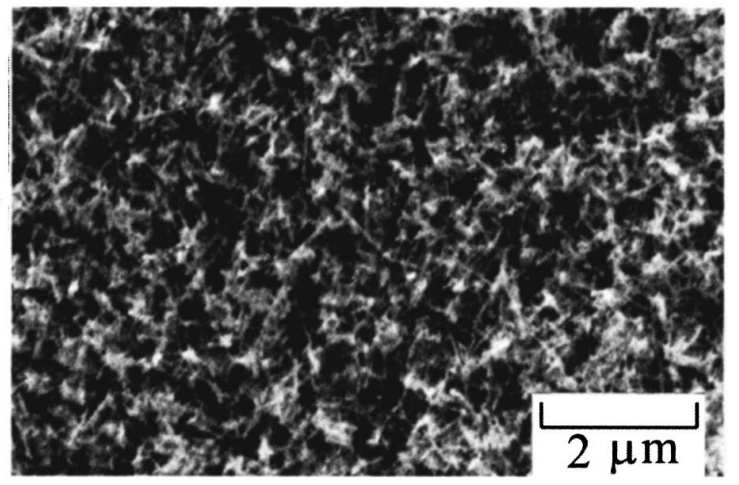

(b)

FIG. 5. SEM micrograph (a) of an ITO film (ITO 7) grown at $300{ }^{\circ} \mathrm{C}$, and (b) air annealed at $400{ }^{\circ} \mathrm{C}-30 \mathrm{~min}$.

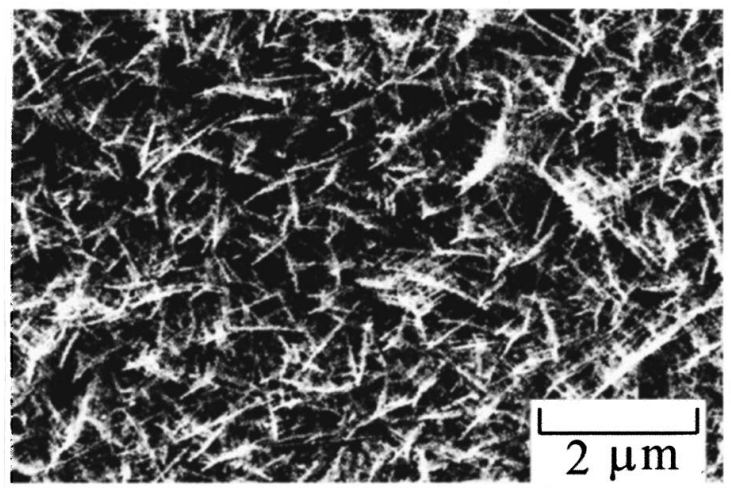

(a)

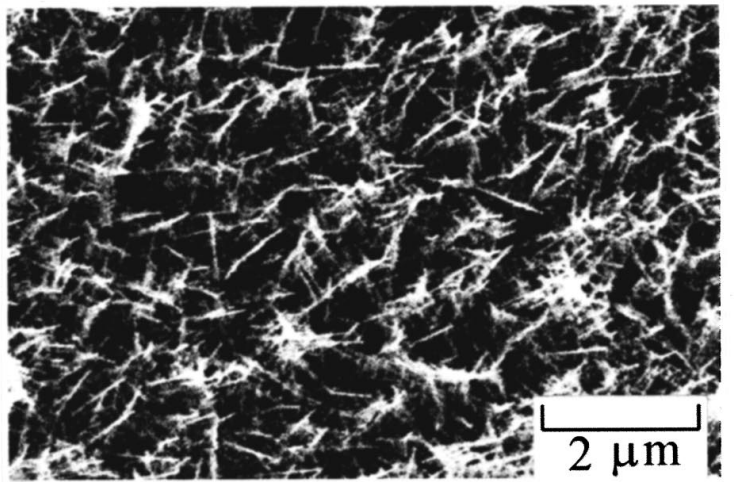

(b)

FIG. 6. SEM micrograph (a) of an ITO film (ITO 6) grown at $250^{\circ} \mathrm{C}$, and (b) air annealed at $400{ }^{\circ} \mathrm{C}-30 \mathrm{~min}$.

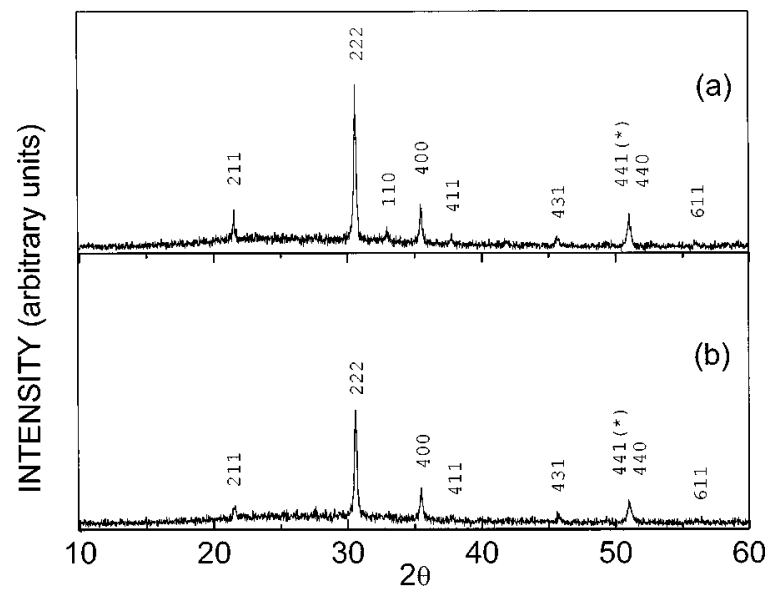

FIG. 7. X-ray difractograms $(\theta-2 \theta)$ of ITO 7 sample of $600 \mathrm{~nm}$ thickness, (a) ITO 7: deposited at $300{ }^{\circ} \mathrm{C}$ on glass and (b) ITO 7T.T.400: further air annealed at $400{ }^{\circ} \mathrm{C}-30 \mathrm{~min}$.

sive analysis of $\mathrm{x}$-rays (EDAX) composition has been measured systematically. Crystal structure, morphology, optical transmittance and reflectance, and sheet resistance have also been studied.

\section{EXPERIMENT}

The vacuum chamber was pumped successively by a rotary rough pump, a turbomolecular pump, and an additional ionic pump, the base vacuum being $<1 \times 10^{-7}$ Torr. Hot pressed powder consisting of $87 \% \quad \mathrm{In}_{2} \mathrm{O}_{3}-13 \% \quad \mathrm{SnO}_{2}$ by weight, typically $99.999 \%$ pure (special-E supplied by CERAC Inc.), was evaporated from a $4 \mathrm{kV} \mathrm{dc}-2 \mathrm{~kW}$ electron gun with magnetic deflection and a water-cooled copper crucible. Film substrates were glass microscope slides and graphite disks that allow optical transmittance and EDAX composition measurements to be made. Substrate temperatures were between 90 and $400{ }^{\circ} \mathrm{C}$ (thermocouple on substrate while heating with halogen $500 \mathrm{~W}$ lamps). During evaporation, the pressure was kept in the $2 \times 10^{-6}-1$ $\times 10^{-5}$ Torr. The beam current was chosen to have a deposition rate of around $35 \AA / \mathrm{min}$. After deposition, annealing at

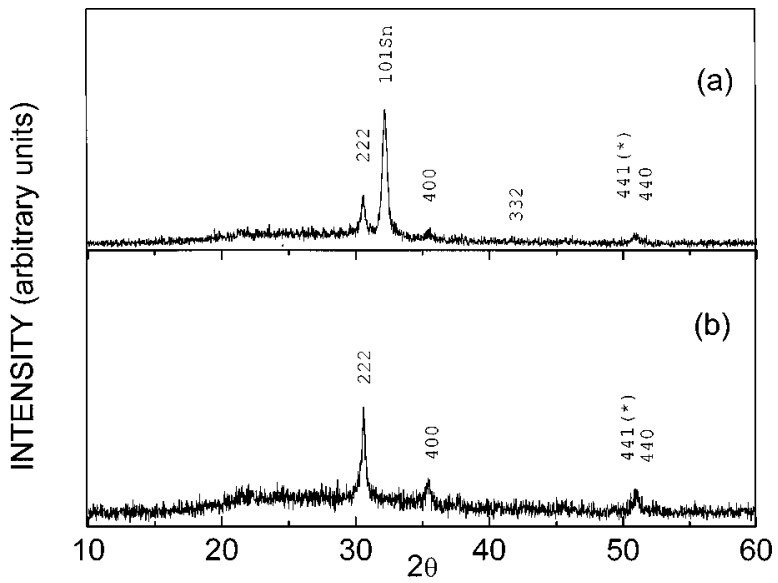

FIG. 8. X-ray difractograms $(\theta-2 \theta)$ of ITO 2 sample of $400 \mathrm{~nm}$ thickness, (a) ITO 2: deposited at $120^{\circ} \mathrm{C}$ on glass and (b) ITO 2T.T.400: further air annealed at $400{ }^{\circ} \mathrm{C}-30 \mathrm{~min}$. 


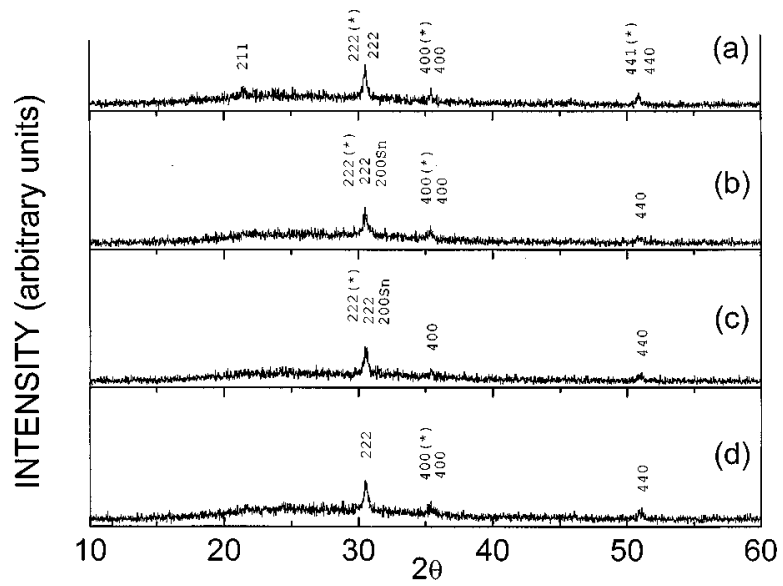

FIG. 9. X-ray difractograms $(\theta-2 \theta)$ of ITO 5 sample of $390 \mathrm{~nm}$ thickness, (a) ITO 5: as deposited at $200{ }^{\circ} \mathrm{C}$ on glass, (b) ITO 5T.T.200: further air annealed at $200^{\circ} \mathrm{C}-30 \mathrm{~min}$, (c) ITO 5T.T.350: further air annealed at $350{ }^{\circ} \mathrm{C}-30 \mathrm{~min}$, and (d) ITO 5T.T.400: further air annealed at $400{ }^{\circ} \mathrm{C}-30$ $\min$.

different temperatures was carried out in air during $30 \mathrm{~min}$. The film thickness was measured with a stylus type apparatus (Talystep, Taylor \& Hobson, U.K.) in the range of 0.15$1.2 \mu \mathrm{m}$. The surface topography and EDAX were performed in a Philips XL 30 scanning electron microscope (SEM). Atomic composition by EDAX was measured, in "asgrown" films on graphite for In, Sn, and O determination, and in as-grown and annealed films on glass substrate for In and Sn relative concentrations. X-ray photoelectron spectroscopy (XPS) was measured in some films on glass substrate, in "as-grown" and annealed states. The XPS studies were performed in a VG-ESCALAB Model 210 apparatus with a vacuum better than $1 \times 10^{-10}$ Torr. The specimens were irradiated with $\mathrm{Mg} K \alpha$ of energy $1253.6 \mathrm{eV}$ from a source of $20 \mathrm{~mA}-12 \mathrm{kV}, 50 \mathrm{eV}$ analyzer and step size $0.45 \mathrm{eV}$. ITO was a good conductor so that no charging effects were observed.

Crystal structure was assessed with a Siemens D-5000 diffractometer for the thicker films (thickness $>0.39 \mu \mathrm{m}$ ).
Grain size was determined by the Scherrer method from $\theta-2 \theta$ diffraction diagrams.

The Van der Pauw method was used for carrier measurements at room temperature, the Hall setup had a field strength of $7 \mathrm{kG}$. Optical transmittance and reflectance were obtained by means of a Cary 17D double beam spectrophotometer. A model assuming multiple reflections in flat compact films was used and in some cases an apparent absorption coefficient $\alpha$ was found. ${ }^{14,15}$ The analysis of $\alpha$ was used to determine the band gaps.

In order to summarize the properties of the ITO films as transparent electrodes, the two figures of merit were used. The first one was proposed by Fraser and Cook, $F_{\mathrm{TC}}$ $=T / R_{S}$, where $T$ is the mean value of transmittance in the visible and $R_{S}$ the sheet resistance. ${ }^{16}$ For the second one, Haacke uses $\phi_{\mathrm{TC}}=T^{10} / R_{S}$, the 10th power being justified by multiple reflections. ${ }^{17}$ Both figures of merit have been determined in the present work.

\section{RESULTS AND DISCUSSION}

The first remarkable SEM observation on all the films grown by electron beam evaporation is their fibrous texture, for they consist mainly of long whiskers $0.5-1 \mu \mathrm{m}$ in length and diameter 450-2000 $\AA$ with no apparent preferential orientation. This has been observed for substrate temperatures in the $120 \leqslant T_{S} \leqslant 400{ }^{\circ} \mathrm{C}$ range and low deposition rates (about $35 \AA / \mathrm{min}$ ).

For samples obtained at $300 \leqslant T_{S} \leqslant 400{ }^{\circ} \mathrm{C}$, the filaments become dendritic with many branches. In Fig. 1 the micrograph of a film grown at $T_{S}=350{ }^{\circ} \mathrm{C}$ is shown. In Figs. 2(a) and 2(b) are shown films grown at $T_{S}=400{ }^{\circ} \mathrm{C}$ with different magnifications. In Fig. 3(a) is shown the side view of the deposits indicating that the whiskers start to grow from a more compact thin layer (about $500 \AA$ in a film of $5000 \AA$ total thickness) at the glass substrate $\left(T_{S}=400{ }^{\circ} \mathrm{C}\right)$. In other cases the whiskers grow from the glass without an intermediate layer as is shown in Fig. 3(b) $\left(T_{S}=365^{\circ} \mathrm{C}\right)$. On annealing in air at temperatures well above that of growth $\left(\Delta T \geqslant 100{ }^{\circ} \mathrm{C}\right)$, the whiskers sometimes reorient and associ-

TABLE I. Structural properties and composition of some ITO samples on glass substrate. Cumulative annealing of $30 \mathrm{~min}$ in air.

\begin{tabular}{|c|c|c|c|c|c|c|c|c|}
\hline Sample & $\begin{array}{l}\text { Growth } \\
\text { temp. }\left({ }^{\circ} \mathrm{C}\right)\end{array}$ & $\begin{array}{l}\text { Annealing } \\
\text { temp. }\left({ }^{\circ} \mathrm{C}\right)\end{array}$ & $\begin{array}{l}\text { Structure } \\
\left(\mathrm{In}_{2} \mathrm{O}_{3}\right)\end{array}$ & $a(\AA)$ & $\begin{array}{c}\text { Grain } \\
\text { size }(\AA)\end{array}$ & {$[\mathrm{Sn}] /[\mathrm{In}]$} & \multicolumn{2}{|c|}{ Other phases-structure } \\
\hline ITO 1 & 90 & - & Cubic & 10.138 & 140 & 0.15 & Sn & Tetragonal \\
\hline ITO 1T.T.400 & 90 & 400 & Cubic & 10.131 & 144 & 0.11 & $\mathrm{Sn}$ & Tetragonal \\
\hline ITO 2 & 120 & - & Cubic & 10.136 & 264 & 0.16 & $\begin{array}{l}\operatorname{In}_{2} \mathrm{Sn}_{2} \mathrm{O}_{(7-x)} \\
\mathrm{Sn}\end{array}$ & $\begin{array}{r}\text { Cubic } \\
\text { Tetragonal }\end{array}$ \\
\hline ITO 2T.T.400 & 120 & 400 & Cubic & 10.126 & 255 & 0.13 & - & \\
\hline ITO 5 & 200 & - & Cubic & 10.132 & 391 & 0.13 & $\mathrm{In}_{2} \mathrm{Sn}_{2} \mathrm{O}_{(7-x)}$ & Cubic \\
\hline ITO 5T.T.200 & 200 & 200 & Cubic & 10.149 & 358 & 0.15 & $\begin{array}{l}\mathrm{Sn} \\
\mathrm{In}_{2} \mathrm{Sn}_{2} \mathrm{O}_{(7-x)}\end{array}$ & $\begin{array}{r}\text { Tetragonal } \\
\text { Cubic }\end{array}$ \\
\hline ITO 5T.T.350 & 200 & 350 & Cubic & 10.110 & 791 & 0.16 & $\begin{array}{l}\mathrm{Sn} \\
\mathrm{In}_{2} \mathrm{Sn}_{2} \mathrm{O}_{(7-x)}\end{array}$ & $\begin{array}{r}\text { Tetragonal } \\
\text { Cubic }\end{array}$ \\
\hline ITO 5T.T.400 & 200 & 400 & Cubic & 10.118 & 302 & 0.15 & - & \\
\hline ITO 7 & 300 & - & Cubic & 10.126 & 450 & 0.06 & - & \\
\hline ITO 7T.T.400 & 300 & 400 & Cubic & 10.124 & 454 & 0.04 & - & \\
\hline ITO 10 & 400 & - & Cubic & 10.140 & 448 & 0.06 & - & \\
\hline
\end{tabular}




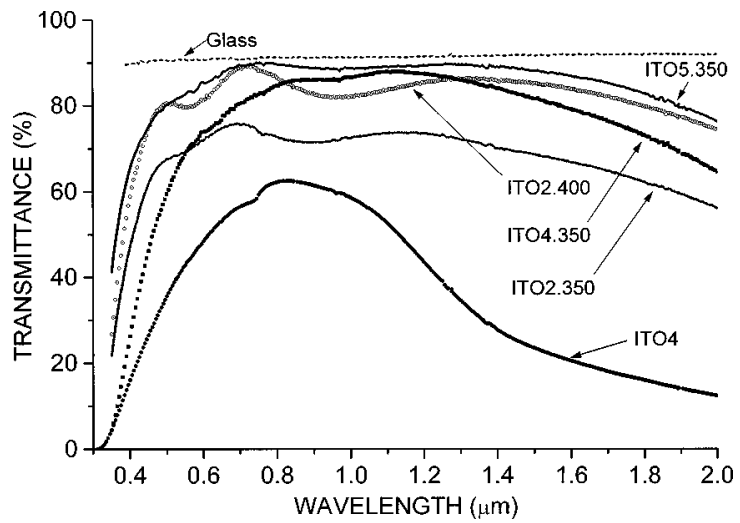

FIG. 10. Transmittance as a function of wavelength of selected ITO films, as-grown (ITO 4) and after cumulative $30 \mathrm{~min}$ air annealings up to the temperature indicated by the last three digits.

ate, forming a sort of tissue [Figs. 4(a), 4(b)]. At other times, they partially collapse [Figs. 5(a), 5(b)] or show no noticeable change in morphology [Figs. 6(a), 6(b)]. By air annealing, the sheet resistance increases by around a factor of 4 , at most.

A typical $\mathrm{x}$-ray diffraction diagram of the film is shown in Figs. 7(a) and 7(b). The reflections are assigned to planes [222], [211], [110], [400], [411], [431], [440], and [661] of the cubic phase of $\operatorname{In}_{2} \mathrm{O}_{3}$. For $T_{S} \leqslant 200{ }^{\circ} \mathrm{C}$, in some "asgrown" films tetragonal $\mathrm{Sn}$ phase appears, with prominent [101] reflection peak shown in Fig. 8(a). In other films, this sequence appears after annealing in air at growth temperature [see sample ITO 5 in Figs. 9(a)-9(d)]. This points towards Sn concentrations far above the $6 \%$ solubility limit for films grown at $T_{S}<300{ }^{\circ} \mathrm{C}$. No preferential orientation has been found in the $\operatorname{In}_{2} \mathrm{O}_{3}$ base phase. However, at $120{ }^{\circ} \mathrm{C}$ substrate temperature, the tetragonal $\mathrm{Sn}$ metal phase has been detected with a strong [101] preferential orientation.

On annealing in air [Figs. 7(b), 8(b), 9(b)-9(d)], the metallic Sn peak vanishes, and weak reflections (marked with asterisks) frequently appear, that could be assigned to cubic $\mathrm{In}_{2} \mathrm{Sn}_{2} \mathrm{O}_{(7-x)}$; in particular, reflection [441] seems stable up to $350{ }^{\circ} \mathrm{C}$ in annealed films. The weak peaks assigned to the cubic $\operatorname{In}_{2} \mathrm{Sn}_{2} \mathrm{O}_{(7-x)}$ phase also appear in some as-grown films. Cubic $\operatorname{In}_{2} \mathrm{O}_{3}$ appears as the only phase in samples grown at $T_{S} \geqslant 300^{\circ} \mathrm{C}$.
Table I summarizes for some samples the x-ray structural properties of as-grown and after air annealing films. The phases that accompany the $\operatorname{In}_{2} \mathrm{O}_{3}$ cubic phase, tetragonal Sn and cubic $\operatorname{In}_{2} \mathrm{Sn}_{2} \mathrm{O}_{(7-x)}$, are indicated, as well as the $\mathrm{Sn} / \mathrm{In}$ concentration ratio as determined by EDAX. The lattice constant of $\mathrm{In}_{2} \mathrm{O}_{3}(a=10.118 \AA$ American Society for Testing and Materials value ${ }^{18}$ ) seems to depend on $T_{S}$ during growth and on air annealing temperature $\left(T_{A}\right)$, the observed values ranging from 10.149 to $10.110 \AA$. The samples deposited at lower temperatures present a lattice constant larger than those deposited at higher temperatures or annealed at $400{ }^{\circ} \mathrm{C}$, with the exception of sample ITO 10 , deposited at $400{ }^{\circ} \mathrm{C}$ and presenting $a=10.140 \AA$. The ionic radius of $\mathrm{In}^{3+}(0.93 \AA)$ is larger than that of $\mathrm{Sn}^{4+}(0.83 \AA)$ and the covalent radii are similar (1.405 $\AA$ for both In and Sn). ${ }^{19}$ Therefore, the increase in lattice constant suggests the presence of interstitial $\mathrm{Sn}$, besides that of substitutional Sn, mainly in samples grown at lower substrate temperatures, $T_{S}<300{ }^{\circ} \mathrm{C}$. Annealing in air up to $350{ }^{\circ} \mathrm{C}$ produces the segregation of metallic $\mathrm{Sn}$ and $\mathrm{In}_{2} \mathrm{Sn}_{2} \mathrm{O}_{(7-x)}$ phases. At $400{ }^{\circ} \mathrm{C}$, the disappearance of $\operatorname{In}_{2} \mathrm{Sn}_{2} \mathrm{O}_{(7-x)}$ phase, the EDAX value of $\mathrm{Sn} / \mathrm{In}$ ratio of $15 \%$ and the high $\mathrm{Sn} / \mathrm{In}$ surface concentration ratio of $460 \%$ found by XPS in a similar annealed sample (ITO 2T.T.400), suggest that $\mathrm{Sn}$ migrates to the surface. The absence of metallic $\mathrm{Sn}$ and $\mathrm{In}_{2} \mathrm{Sn}_{2} \mathrm{O}_{(7-x)}$ phases when $T_{S} \geqslant 300^{\circ} \mathrm{C}$ is associated with a $\mathrm{Sn} / \mathrm{In}$ concentration ratio of around 6\%, the solubility limit proposed by Frank et al. ${ }^{8}$

We would like to point out the difference between the presence of Sn metal in our films and the presence of In metal observed in ITO films when deposited by sputtering, without oxygen in the discharge. ${ }^{1}$

The grain size, as determined by the Scherrer method from the peak width at half maximum, increases as a function of the substrate temperature up to $450-2000 \AA$ and assessed by SEM observations [see Figs. 2(b) and 3(b), respectively]. After further annealing in air, in some cases the grain size increases from 390 to $790 \AA$ (see sample ITO 5 in Table 1: $T_{S}=200^{\circ} \mathrm{C}-T_{A}=350{ }^{\circ} \mathrm{C}$ ). The observations in SEM show [Fig. 4(a), 4(b), and 5(a)] that on annealing the fibers collapse and the films become more compact. This is simultaneous to an increase in the optical transmittance in the $0.4-0.8 \mu \mathrm{m}$ range (see Fig. 10).

TABLE II. EDAX measurements of ITO films on graphite substrate as-grown.

\begin{tabular}{|c|c|c|c|c|c|c|c|c|}
\hline \multirow[b]{2}{*}{ Sample } & \multirow{2}{*}{$\begin{array}{c}\text { Growth } \\
\text { temp. }\left({ }^{\circ} \mathrm{C}\right)\end{array}$} & $\mathrm{O}$ & $\mathrm{Sn}$ & In & \multirow[b]{2}{*}{$\mathrm{Sn} /(\mathrm{In}+\mathrm{Sn})$} & \multirow[b]{2}{*}{$\operatorname{In} /(\operatorname{In}+\mathrm{Sn})$} & \multirow[b]{2}{*}[\mathrm{Sn}]{$/[\mathrm{In}]$} & \multirow[b]{2}{*}[\mathrm{Sn}]{$/[\mathrm{O}]$} \\
\hline & & & (at. \%) & & & & & \\
\hline ITO 1 & 90 & 75.94 & 3.33 & 20.76 & 0.136 & 0.864 & 0.157 & 0.043 \\
\hline ITO 2 & 120 & 68.64 & 3.06 & 28.30 & 0.098 & 0.902 & 0.108 & 0.045 \\
\hline ITO 3 & 150 & 68.01 & 2.04 & 29.95 & 0.064 & 0.936 & 0.068 & 0.030 \\
\hline ITO 4 & 180 & 73.49 & 2.41 & 24.10 & 0.090 & 0.910 & 0.099 & 0.033 \\
\hline ITO 5 & 200 & 78.84 & 2.79 & 18.37 & 0.132 & 0.868 & 0.152 & 0.035 \\
\hline ITO 6 & 250 & 58.20 & 2.34 & 39.46 & 0.056 & 0.944 & 0.059 & 0.040 \\
\hline ITO 7 & 300 & 70.41 & 1.69 & 27.90 & 0.057 & 0.943 & 0.060 & 0.024 \\
\hline ITO 8 & 350 & 70.41 & 2.88 & 26.71 & 0.097 & 0.903 & 0.110 & 0.041 \\
\hline ITO 9 & 365 & 72.41 & 1.67 & 25.92 & 0.060 & 0.940 & 0.064 & 0.023 \\
\hline ITO 10 & 400 & 70.04 & 1.46 & 20.50 & 0.062 & 0.938 & 0.066 & 0.021 \\
\hline
\end{tabular}


TABLE III. EDAX measurements of some ITO films on glass substrate as-grown and cumulative annealing 30 min in air.

\begin{tabular}{lcccrc}
\hline \hline & Growth & Annealing & & In & Sn \\
\cline { 4 - 5 } Sample & temp. $\left({ }^{\circ} \mathrm{C}\right)$ & temp. $\left({ }^{\circ} \mathrm{C}\right)$ & & \\
& 90 & - & 86.96 & 13.04 & 0.15 \\
ITO 1 & 90 & 400 & 90.25 & 9.75 & 0.11 \\
ITO 1T.T.400 & 120 & - & 86.21 & 13.79 & 0.16 \\
ITO 2 & 120 & 400 & 88.47 & 1.53 & 0.13 \\
ITO 2T.T.400 & 150 & - & 94.95 & 5.05 & 0.05 \\
ITO 3 & 150 & 400 & 95.02 & 4.98 & 0.05 \\
ITO 3T.T.400 & 180 & - & 92.79 & 7.21 & 0.08 \\
ITO 4 & 180 & 300 & 94.65 & 5.35 & 0.06 \\
ITO 4T.T.300 & 180 & 400 & 95.81 & 4.19 & 0.04 \\
ITO 4T.T.400 & 200 & - & 88.71 & 11.29 & 0.13 \\
ITO 5 & 200 & 200 & 87.21 & 2.79 & 0.15 \\
ITO 5T.T.200 & 200 & 350 & 86.25 & 13.75 & 0.16 \\
ITO 5T.T.350 & 200 & 400 & 86.84 & 13.16 & 0.15 \\
ITO 5T.T.400 & 250 & - & 95.67 & 4.33 & 0.04 \\
ITO 6 & 250 & 400 & 95.68 & 4.32 & 0.04 \\
ITO 6T.T.400 & 300 & - & 94.27 & 5.73 & 0.06 \\
ITO 7 & 300 & 400 & 95.93 & 4.07 & 0.04 \\
ITO 7T.T.400 & 350 & - & 89.56 & 10.44 & 0.12 \\
ITO 8 & 350 & 400 & 92.90 & 7.10 & 0.08 \\
ITO 8T.T.400 & 365 & - & 96.55 & 3.45 & 0.04 \\
ITO 9 & 365 & 400 & 97.14 & 2.86 & 0.03 \\
ITO 9T.T.400 & 400 & - & 95.91 & 4.09 & 0.06 \\
ITO 10 & 400 & 400 & 95.88 & 4.12 & 0.04 \\
ITO 10T.T.400 & & & & & \\
\hline \hline & & & & & \\
\hline
\end{tabular}

TABLE IV. XPS measurements of some ITO on glass substrate, as-grown and annealed films.

\begin{tabular}{|c|c|c|c|c|c|c|c|}
\hline \multirow[b]{2}{*}{ Sample } & $\mathrm{O}$ & Sn & In & $\mathrm{C}$ & \multirow[b]{2}{*}[\mathrm{Sn}]{$/[\mathrm{In}]$} & \multirow[b]{2}{*}{$\mathrm{Sn} /(\mathrm{In}+\mathrm{Sn})$} & \multirow[b]{2}{*}{$\mathrm{In} /(\mathrm{In}+\mathrm{Sn})$} \\
\hline & \multicolumn{4}{|c|}{ (at. \%) } & & & \\
\hline ITO 2 & 46.050 & 5.070 & 27.360 & 21.520 & 0.185 & 0.156 & 0.844 \\
\hline ITO 2T.T.400 & 39.415 & 27.562 & 5.997 & 27.026 & 4.596 & 0.821 & 0.179 \\
\hline ITO 7 & 32.938 & 8.102 & 20.413 & 38.547 & 0.397 & 0.284 & 0.716 \\
\hline ITO 7T.T.400 & 42.841 & 9.314 & 22.763 & 25.082 & 0.409 & 0.290 & 0.710 \\
\hline
\end{tabular}

TABLE V. Transport and optical properties of as-grown ITO films on glass substrate.

\begin{tabular}{lcccccccc}
\hline \hline Sample & $\begin{array}{c}\text { Growth } \\
\text { temp. }\left({ }^{\circ} \mathrm{C}\right)\end{array}$ & $\begin{array}{c}\text { Thickness } \\
(\mu \mathrm{m})\end{array}$ & $\begin{array}{c}R_{s} \\
(\Omega / \square)\end{array}$ & $\begin{array}{c}\text { Resistivity } \\
\Omega \mathrm{cm}\end{array}$ & $\begin{array}{c}\text { Mobility } \\
\mathrm{cm}^{2} / \mathrm{V} \mathrm{s}\end{array}$ & $\begin{array}{c}\text { Carrier } \\
\text { density } \\
10^{20} \mathrm{~cm}^{-3}\end{array}$ & $\begin{array}{c}\text { Direct } \\
E_{g 1} \\
(\mathrm{eV})\end{array}$ & $\begin{array}{c}\text { Direct } \\
E_{g 2} \\
(\mathrm{eV})\end{array}$ \\
\hline ITO 1 & 90 & 0.40 & 123 & $4.16 \times 10^{-3}$ & 2.70 & 5.50 & 1.01 & 1.33 \\
ITO 2 & 120 & 0.40 & 21 & $7.98 \times 10^{-4}$ & 5.37 & 14.60 & 0.71 & 1.42 \\
ITO 3 & 150 & 1.17 & 20 & $9.05 \times 10^{-4}$ & 5.65 & 11.20 & --- & -- \\
ITO 4 & 180 & 0.58 & 61 & $3.33 \times 10^{-3}$ & 6.79 & 2.76 & 1.70 & 2.21 \\
ITO 5 & 200 & 0.39 & 78 & $2.91 \times 10^{-3}$ & 6.88 & 3.12 & 1.44 & 1.99 \\
ITO 6 & 250 & 1.05 & 28 & $2.90 \times 10^{-3}$ & 4.34 & 4.90 & --- & --- \\
ITO 7 & 300 & 0.60 & 29 & $1.10 \times 10^{-3}$ & 7.07 & 7.78 & --- & --- \\
ITO 8 & 350 & 0.80 & 41 & $3.09 \times 10^{-3}$ & 5.08 & 3.98 & --- & --- \\
ITO 10 & 400 & 0.45 & 21 & $8.13 \times 10^{-4}$ & 7.12 & 1.22 & --- & --- \\
\hline \hline
\end{tabular}


The EDAX measurements are summarized in Table II for "as-grown" films on graphite substrate and Table III on glass substrate and further annealing in air. In the ITO films deposited on graphite at $T_{S} \leqslant 250{ }^{\circ} \mathrm{C}$, the Sn content exceeds by about a factor of 2 the 6 at. \% solubility limit of $\mathrm{Sn}$ in $\mathrm{In}_{2} \mathrm{O}_{3}$, while at higher temperatures $\left(T_{S} \geqslant 300{ }^{\circ} \mathrm{C}\right)$ the concentration is about 6 at. \% decreasing to 4 at. $\%$ on annealing at $400{ }^{\circ} \mathrm{C}$ in air. On further annealing in air of films on glass substrates, the detected Sn/In ratio decreases, which would also be consistent with segregation of $\mathrm{Sn}$ to the surface. The low Sn content $(\approx 4$ at. $\%)$ in samples further annealed at $400{ }^{\circ} \mathrm{C}$ is remarkable and suggests that, apart from surface segregation, some reevaporation of $\mathrm{SnO}_{2}$ takes place. EDAX measurements have been also done on the film cross section, after splitting the glass substrate. For $T_{S}=365{ }^{\circ} \mathrm{C}$, in the outer film side consisting of whiskers, the $\mathrm{Sn} / \mathrm{In}$ concentration ratio is less than $50 \%$ of that of the film side close to the substrate, i.e., about 3\% and 7\%, respectively. For higher substrate temperature $\left(T_{S}=400{ }^{\circ} \mathrm{C}\right)$ the difference in $\mathrm{Sn} / \mathrm{In}$ concentration ratio between the whiskers and the film inner layer decreases, i.e., $2.6 \%$ and $3.2 \%$, respectively.

Surface composition XPS measurements on two films on glass substrate both in as-grown state and after annealing in air, are shown in Table IV. In the as-grown state film at $T_{S}$ $=120^{\circ} \mathrm{C}$, an atomic ratio $[\mathrm{Sn}] /[\mathrm{In}] \approx 18.5$ at. $\%$ similar to the EDAX $15.7 \%$ value was found. On annealing in air, there is an important increase of $[\mathrm{Sn}] /[\mathrm{In}]$ concentration ratio at the surface $(\approx 460 \%)$. There is a certain growth in $C$ content, and at the same time the oxygen content decreases on the air annealed sample. As in this annealed sample no phase other than $\operatorname{In}_{2} \mathrm{O}_{3}$ has been detected (see Table I), the migration of Sn to the surface seems to be the means of releiving stress from the lattice. In the sample grown at $300{ }^{\circ} \mathrm{C}$, the increase of $\mathrm{Sn}$ at the surface takes place during growth, up to $[\mathrm{Sn}] /[\mathrm{In}] \approx 40$ at. $\%$ and does not change much on further air annealing $([\mathrm{Sn}] /[\mathrm{In}] \approx 41$ at. \%), possibly due to the fact that the as-grown bulk concentration is close to the saturation value (6 at. \%). The data of Table I of lattice constants of samples ITO 2 and ITO 7 after annealing to $400{ }^{\circ} \mathrm{C}, a$ $=10.126 \AA$ and $a=10.124 \AA$, may be related to the value of the $\mathrm{Sn}$ saturated lattice.

In as-grown films, the spectral optical transmittance does not show interference maxima and minima, as could be expected from a rough surface. For $T_{\mathrm{s}}$ above $250{ }^{\circ} \mathrm{C}$, the films present a milky aspect to the naked eye, keeping a large

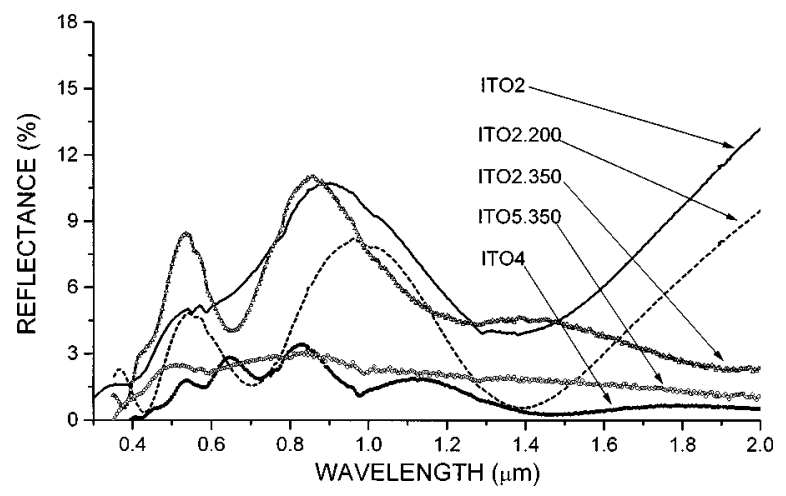

FIG. 11. Reflectance as a function of wavelength of selected ITO films, as-grown (ITO 2, ITO 4) and after cumulative $30 \mathrm{~min}$ air annealings up to the temperature indicated by the last three digits.

transmittance in the visible range. Figure 10 curve ITO 4 shows the optical transmittance of the more representative as-grown ITO films.

In Table V, transport and optical properties are shown. In the as-grown form, the low substrate temperature films present an anomalous direct energy gap in the $0.7-1.7 \mathrm{eV}$ range, that may be attributed to the presence of $\operatorname{In}_{2} \mathrm{Sn}_{2} \mathrm{O}_{(7-x)}$ phases and metallic Sn tetragonal phase. The sheet resistance for a film with an apparent thickness of $4000 \AA$, as measured with a "Talystep" profile apparatus, is $21 \Omega / \square$. With this apparent thickness, the resistivity and carrier concentration values obtained should be interpreted only as an indicative resistivity of the bulk material. The optical band gaps quoted for the films are also indicative, as the model used refers to a compact film. However, the clearly lower energy gaps may be attributed to phases other than cubic $\operatorname{In}_{2} \mathrm{O}_{3}$.

Air annealing at $200{ }^{\circ} \mathrm{C}$ for 30 min produces increases in transmittance in the visible range, up to $14 \%$ and a decrease in reflectance in the near IR, of $1 \%$. Further annealing above $200{ }^{\circ} \mathrm{C}$ in air increases reflectance in the visible range up to $2 \%-3 \%$, and decreases it in the near IR, down to $1 \%$ (see Fig. 11). The appearance of interference maxima and minima suggests a reduction of the surface roughness on annealing. Table VI summarizes the results of the electrical and optical properties of the film after successive annealings in air. The resistance square increases with annealing, in spite of the possible increase in the effective cross section of the compact part of the film, as whiskers connect or collapse and

TABLE VI. Transport and optical properties ITO samples after annealing in air for $30 \mathrm{~min}$.

\begin{tabular}{lccccccc}
\hline \hline & & & \multicolumn{2}{c}{ Carrier } \\
Sample & $\begin{array}{c}\text { Annealing } \\
\text { temp. }\left({ }^{\circ} \mathrm{C}\right)\end{array}$ & $\begin{array}{c}\text { Resistivity } \\
(\Omega \mathrm{cm})\end{array}$ & $\begin{array}{c}\text { Mobility } \\
\left(\mathrm{cm}^{2} / \mathrm{V} \mathrm{s}\right)\end{array}$ & $\begin{array}{c}\text { Density } \\
10^{19} \mathrm{~cm}^{-3}\end{array}$ & $\begin{array}{c}\text { Direct } \\
E_{g 1}(\mathrm{eV})\end{array}$ & $\begin{array}{c}\text { Direct } \\
E_{g 2}(\mathrm{eV})\end{array}$ & $\begin{array}{c}\text { Forbidden } \\
E_{g} \\
(\mathrm{eV})\end{array}$ \\
\hline ITO 1T.T.300 & 300 & $4.05 \times 10^{-3}$ & 14.70 & 10.50 & 1.72 & 2.20 & 2.85 \\
ITO 1T.T.400 & 400 & $1.36 \times 10^{-2}$ & 16.70 & 2.75 & --- & 2.71 & 3.06 \\
ITO 2T.T.400 & 400 & $4.66 \times 10^{-3}$ & 3.88 & 32.90 & 2.43 & 3.06 & -- \\
ITO 4T.T.350 & 350 & $3.57 \times 10^{-2}$ & 8.85 & 1.95 & 1.74 & 2.30 & -- \\
ITO 5T.T.300 & 300 & $7.04 \times 10^{-2}$ & 5.82 & 1.52 & --- & 2.40 & 2.99 \\
ITO 5T.T.400 & 400 & $1.19 \times 10^{-2}$ & 6.87 & 7.64 & --- & 2.64 & 3.01 \\
\hline \hline
\end{tabular}


TABLE VII. Comparison of figure-of-merit values $F_{\mathrm{TC}}$ and $\phi_{\mathrm{TC}}$ of ITO films after annealing in air for $30 \mathrm{~min}$.

\begin{tabular}{|c|c|c|c|c|c|c|c|c|c|c|}
\hline \multirow[b]{2}{*}{ Sample } & \multirow{2}{*}{$\begin{array}{c}R_{\mathrm{s}} \\
{[\Omega / \square]}\end{array}$} & \multicolumn{3}{|c|}{$\begin{array}{c}\text { Transmittance \% at } \\
\text { different wavelengths }(\mu \mathrm{m})\end{array}$} & \multicolumn{3}{|c|}{$\begin{array}{l}F_{\mathrm{TC}}\left[10^{-3} \Omega^{-1}\right] \text { at } \\
\text { different wavelengths }(\mu \mathrm{m})\end{array}$} & \multicolumn{3}{|c|}{$\begin{array}{c}\phi_{\mathrm{TC}}\left[10^{-3} \Omega^{-1}\right] \text { at } \\
\text { different wavelengths }(\mu \mathrm{m})\end{array}$} \\
\hline & & 0.60 & 0.65 & 0.70 & 0.60 & 0.65 & 0.70 & 0.60 & 0.65 & 0.70 \\
\hline ITO 1T.T.400 & 778 & 76 & 76 & 86 & 1.0 & 1.0 & 1.1 & 0.08 & 0.08 & 0.28 \\
\hline ITO 2T.T.300 & 241 & 70 & 70 & 71 & 2.9 & 2.9 & 2.9 & 0.12 & 0.12 & 0.13 \\
\hline ITO 2T.T.350 & 251 & 72 & 75 & 76 & 2.9 & 3.0 & 3.0 & 0.15 & 0.22 & 0.22 \\
\hline ITO 2T.T.400 & 280 & 81 & 86 & 90 & 2.9 & 3.1 & 3.2 & 0.43 & 0.79 & 1.24 \\
\hline ITO 4T.T.200 & 106 & 51 & 56 & 59 & 4.8 & 5.3 & 5.6 & 0.01 & 0.03 & 0.05 \\
\hline ITO 4T.T.300 & 118 & 64 & 67 & 71 & 5.4 & 5.7 & 6.0 & 0.10 & 0.15 & 0.28 \\
\hline ITO 4T.T.350 & 287 & 74 & 77 & 80 & 2.6 & 2.7 & 2.8 & 0.17 & 0.25 & 0.37 \\
\hline ITO 5T.T.200 & 340 & 64 & 67 & 71 & 1.9 & 2.0 & 2.1 & 0.03 & 0.05 & 0.10 \\
\hline ITO 5T.T.300 & 342 & 78 & 80 & 83 & 2.3 & 2.3 & 2.4 & 0.24 & 0.31 & 0.45 \\
\hline ITO 5T.T.350 & 387 & 85 & 87 & 89 & 2.2 & 2.2 & 2.3 & 0.51 & 0.64 & 0.81 \\
\hline ITO 5T.T.400 & 627 & 83 & 85 & 88 & 1.3 & 1.4 & 1.4 & 0.25 & 0.31 & 0.44 \\
\hline
\end{tabular}

increase in grain size. This would point towards a reduction of free electron concentration in the bulk as Sn atoms diffuse to the surface.

In Table VII, the transmittance versus sheet resistance ratios and the values of figures of merit $F_{\mathrm{TC}}$ and $\phi_{\mathrm{TC}}$ at different wavelength intervals in the visible range, for a series of samples after annealing in air, are summarized. These figures are similar to values reported by other authors. ${ }^{4,17}$

The lattice constant decreases slightly when annealing in air, and so does the apparent conductivity of the film. This would indicate that, besides $\mathrm{Sn}$ as metallic phase, there are some Sn atoms as interstitials that take the "normal" substitutional position in the In sublattice and/or leave the crystal segregating to the surface.

\section{CONCLUSIONS}

Thin films of ITO with high fiber content have been grown by $e$-beam evaporation and without electron shower.

The observation of metallic Sn in ITO films deposited at low substrate temperature indicates that $e$-beam evaporation of ITO produces the decomposition of $\mathrm{SnO}_{2}$. Substrate temperatures above $200{ }^{\circ} \mathrm{C}$ induce the $\mathrm{Sn}$ to pass into solution. Whiskers are readily formed in this way, increasing in size and branching as growth temperature increases, thus suggesting a correlation with the presence of $\mathrm{Sn}$ in the lattice above the solubility limit. In this work, the saturation values of 6 at. \% observed by Frank and co-workers, are confirmed. Further thermal annealing in air produces $\operatorname{In}_{2} \mathrm{Sn}_{2} \mathrm{O}_{(7-x)}$ and increases the surface concentration of $\mathrm{Sn}$, so that in some cases $80 \%$ are Sn atoms and $20 \%$ In atoms. The resistivity seems related more to free-electron concentration caused by $\mathrm{Sn}$ atoms in the bulk, than to grain size. Testing of the porous ITO films as gas sensors is under way.

\section{ACKNOWLEDGMENTS}

The scholarship awarded to one of us (S. Castañeda) by Instituto de Cooperación Iberoamericana is gratefully acknowledged. This work has been financed in part by ESAs ESTEC Contract No. 10076/92/NL/US/(SC) in collaboration with Construcciones Aeronáuticas S.A., Madrid and CICYT Contract ESP-96-0504. Thanks are due to Dr. B. García Carretero and Dr. J. L. Castaño for helpful discussions, E. Salvador for the SEM and EDAX measurements.

${ }^{1}$ M. C. de Andrade and S. Moehlecke, Appl. Phys. A: Solids Surf. 58, 503 (1994)

${ }^{2}$ I. Hamberg, A. Hjortsberg, and C. Granqvist, Appl. Phys. Lett. 40, 362 (1982).

${ }^{3}$ I. Hamberg, A. Hjortsberg, and C. Granqvist, Proc. SPIE 324, 31 (1982).

${ }^{4}$ R. Banerjee, D. Das, S. Ray, A. K. Batabyal, and A. K. Barua, Sol. Energy Mater. 13, 11 (1986).

${ }^{5}$ I. Elfallal, R. D. Pilkington, A. E. Hill, R. Diaz, M. León, L. Galán, and F. Rueda, in Proceedings of the 11th E. C. Photovoltaic Solar Energy Conference, Montreux, Switzerland, 1992 (unpublished), p. 925.

${ }^{6}$ I. Elfallal, R. D. Pilkington, and A. E. Hill, J. Mater. Sci. 26, 6203 (1991).

${ }^{7}$ I. Hamberg, C. G. Granqvist, K. F. Berggren, B. E. Sernelius, and L. Engstrom, Phys. Rev. B 30, 3240 (1984).

${ }^{8}$ G. Frank, H. Köstlin, and A. Rabenau, Phys. Status Solidi A 52, 231 (1979).

${ }^{9}$ I. Elfallal, R. D. Pilkington, and A. E. Hill, Thin Solid Films 223, 303 (1993).

${ }^{10}$ I. A. Rauf, J. Mater. Sci. Lett. 12, 1902 (1993).

${ }^{11}$ I. A. Rauf, Surf. Sci. 325, L413 (1995).

${ }^{12}$ R. F. Bunshah and R. S. Juntz, Metallurgical Transactions 4, 21 (1973).

${ }^{13}$ H. Yumoto, J. Hatano, T. Watanabe, K. Fujikawa, and H. Sato, Jpn. J. Appl. Phys., Part 1 32, 1204 (1993).

${ }^{14}$ F. Abeles, in Method for Determining Optical Parameters of Thin Films; Progress in Optics, edited by E. Wolf (North-Holland, Amsterdam, 1963).

${ }^{15}$ E. Elizalde and F. Rueda, Thin Solid Films 122, 45 (1984).

${ }^{16}$ D. B. Fraser and H. D. Cook, J. Electrochem. Soc. 119, 1368 (1972).

${ }^{17}$ G. Haacke, J. Appl. Phys. 47, 4086 (1976).

${ }^{18}$ H. E. Swanson, N. T. Gilfrich, and G. M. Ugrinic, Standard X-ray Diffraction Powder Patterns, Natl. Bur. Standards, Circ. 5 539, 26 (1955).

${ }^{19}$ D. K. Adams, Inorganic Solids (Wiley, New York, 1974). 